\title{
А.В. Григоровская
}

\section{СПЕЦИФИКА НАЦИОНАЛЬНОГО ХАРАКТЕРА В ИЗОБРАЖЕНИИ ПРЕДПРИНИМАТЕЛЯ В РОМАНАХ КЭМЕРОНА ХОУЛИ И АЙН РЭНД}

\begin{abstract}
Предлагается сопоставление образов предпринимателя в романах К. Хоули и А. Рэнд. Анализ романов предваряется кратким экскурсом в историю имагологии предпринимателя в русской $и$ американской литературах, а также устанавливаются истоки данных образов у авторов. Сопоставление четырех типов предпринимателей в романах Хоули и Рэнд позволяет сделать вывод о принципиальной разнице в конструировании образа предпринимателя в этих текстах, в первую очередь, обусловленной национальной спечификой их воссоздания.

Ключевые слова: образ предпринимателя в литературе, начиональный характер, русская литература, американская литература, Айн Рэнд, Кэмерон Хоули.
\end{abstract}

Предприниматель как герой художественной литературы - явление, имеющее ярко выраженную национальную специфику. Традиционно предприниматели становились объектом изображения в западноевропейской и американской литературах. Для последней фигура бизнесмена даже стала в определенной степени камнем преткновения, отразив социальные процессы разочарования в капиталистической модели и «американской мечте». При этом в русской литературе образ делового человека столь же традиционно остается «за кадром», а тенденция к негативному изображению предпринимателя усиливается в советское время.

Для понимания причин различий в воссоздании фигуры бизнесмена в американской и русской литературах следует обратиться к генеалогии образа национального героя-предпринимателя. Истоки любого художественного образа можно обнаружить в фольклоре. История американской литературы достаточно недолгая: Ж. Бодрийяр называет американскую культуру «ноль-культурой» [1]. В связи с 
этим Т. Голенопольский отмечает, что история для американской культуры - понятие во многом относительное: «В Америке от неуловимой легенды до запечатления образа в печати требовалось всего лишь несколько лет» [2]. Первыми фольклорными героями, с которыми ассоциировалась американская культура успеха, стали Дэви Крокетт, Дэниел Бун, Майк Финк-лодочник, Пол Баньян, Кем па Морган, Пекос Билл, Питер Франческо. Всех этих героев объединяет авантюризм, смелость, а тексты о них - буффонадный стиль изложения, прием возвышения героя «из грязи в князи». Другой тип национального американского героя создавался по образцу «отцовоснователей» США, таких как Джордж Вашингтон, Томас Джеффресон и Бенджамин Франклин. Это тип отличается уже внутренним благородством и трезвостью рассуждений, имея при том черты «стилизованного полубога». Еще один тип американского национального героя связан с образом американского Робин Гуда, «плохого парня» Билли Кида (Парнишка Билли). Далее массовая культура Америки породила новый типаж - «человека с раздвоенной личностью», Кларка Кента, больше известного как «супермен». Данный образ «мутирует» в так называемого corporate man, интеллектуального супермена, прообразом которого стал Джон Кеннеди. Горацио Алджер-младший создает в массовой литературе миф о преуспевшем герое, который поднялся из самых низов, воплотив в жизнь «американскую мечту». Данный миф сделал «синонимом счастья... индивидуальный успех, а мерилом успеха - деньги» [3. С. 241].

Так на смену романтическому герою Д. Торо, спасавшемуся в трансцендендалистском удалении от общества, пришел self-made man - преуспевающий делец, человек, который сам себя «сделал». При этом критика такого упрощенного понимания «американской мечты», даже ее деградации, осознавалась американской литературой: тоска по романтическому герою Ф. Купера, обладавшему такими чертами, как честность, простодушие и любовь к природе, чувствуется в романах Т. Уайлдера, Ф. Фицджеральда, У. Фолкнера, Ш. Андерсона, Д. дос Пассоса. Так, о кризисе национальной американской идентичности и ее отражении в романах писателей XX в. пишет Е.В. Варламова, отмечая, что он был связан с тем, что «идеалы, которые проповедовали отцы-основатели, мертвы для современных американцев, утративших связь с прошлым, со своими корня- 
ми» [4. C. 7]. Этот же кризис вызвал к жизни романы так называемых макрейкеров, «разгребателей грязи», которые живописали уродства капиталистической системы и воссоздавали образы кровожадных финансистов (Т. Драйзер, Э. Синклер, С. Льюис).

В отличие от американской, русская литература, обладающая давней историей, не имела ярко выраженного образа делового человека. Считается (и совершенно справедливо), что данный тип героя не является характерным для русской литературы. Причину называет Н.Н. Зарубина, говоря о глубинном конфликте между «практической рациональностью» и «ценностной рациональностью» в русской культуре: «Столкновение дворянства и купечества, а также дворянаристократов и дворян-предпринимателей является одной из важнейших тем литературы XIX - начала XX вв. и предстает оно как трагическое столкновение разных нравственных стандартов, разных шкал ценностей, по сути - несоединимых» [5. С. 2].

Данный ценностный конфликт можно считать причиной того, что образ делового человека в русской литературе практически повсеместно имеет негативные коннотации. Уже в первых «пробах» жанра романа в русской литературе в XVIII в. оформляется образ ловкого плута, пикаро, наживающегося на наивных людях (роман В. Нарежного о князе Чистякове). В русской литературе XIX в. галерея образов предприимчивых дельцов дополняется Германном из «Пиковой дамы» А.С. Пушкина, Чичиковым из «Мертвых душ» Н.В. Гоголя, Васильковым из «Бешеных денег» А.Н. Островского, Ермолаем Лопахиным из «Вишневого сада» А.П. Чехова, сопровождаясь, понятное дело, осуждающими коннотациями. Немногочисленные положительно окрашенные образы деловых людей в русской литературе XIX в., что характерно, являются иностранцами (Костанжогло из «Мертвых душ», Штольц из «Обломова»). Связано это, вероятно, с тем, что, как отмечает Недзвецкий, русский предприниматель - «это человек, которому, по словам Алексея Карамазова, “миллиона не надо, а надобно мысль разрешить”, и мысль не бытовую и материальную, а о морали (вере) и аморализме (неверии), о добре и зле, о самой природе человеческой и способах возрождения и спасения ее» [6. С. 76-77].

На рубеже XIX-XX вв. разрыв между двумя типами рациональности в России становится еще более резким. Так, конфликт аристо- 
кратии и предпринимателей живописует в своем романе «Китайгород» (1882) П. Боборыкин: его талантливый предприниматель Евлампий Нетов подвергается гонениям со стороны дворянства, которое стремится его «сломать, перевоспитать, внуша[ет] ему “чинобесие”, несвойственную светскость, необходимость общественной деятельности, славянофильство и прочие модные нелепости» [5. C. 15]. Боборыкин подчеркивает ощущение недооцененности своим персонажем самого же себя, стремящегося что-то доказать аристократии, закономерным считая финал романа, в котором Нетов кончает свои дни в сумасшедшем доме. Такую же недооцененность предпринимателя в русской культуре подчеркнет позднее М. Горький, сообщая высокую миссию русского предпринимателя - заботиться о своем народе, быть рачительным хозяином, для которого деньги не являются самоцелью («Фома Гордеев», «Дело Артамоновых»). Беспокойство о народе, осознание своей причастности к его судьбе ощущают и герои Д. Мамина-Сибиряка («Приваловские миллионы»). При этом иную сторону реальности показывают нам русские писатели-эмигранты «первой волны»: так, М. Алданов в своем романе «Самоубийство» вскроет механизмы Октябрьской революции, совершенной на деньги таких меценатов, как Савва Морозов, и обернувшейся в итоге против них же самих. Резюмируя, можно сказать, что в русской литературе рубежа XIX-XX вв. разрыв между аристократией и предпринимателями, с одной стороны, и между предпринимателями и народом - с другой, не был преодолен, а в советской литературе он был даже усугублен («Угрюм-река» В. Шишкова).

Итак, мы наблюдаем амбивалентность образа предпринимателя как в американской, так и в русской литературах. Обе культуры осознавали кризис философии предпринимательства, выраженный в противопоставлении голой меркантильности и служения идее (и через нее - людям) посредством бизнеса. При этом русская культура имела также сильный разрыв между аристократией и предпринимательством и предпринимательством и народом, тогда как для американской культуры существовал только последний. Что немаловажно, критика «власти денег» в американской литературе во многом основывалась на симпатии социалистической модели развития, по которому пошла Россия в $\mathrm{XX}$ в. 
Сопоставление двух разных национальных моделей функционирования одного художественного образа представляется продуктивным сделать на материале «типично» американского писателя Кэмерона Хоули и «нетипично» американской философа и писательницы Айн Рэнд (Алисы Розенбаум). Данное сопоставление интересно тем, что оба автора являются не просто писателями, а людьми, имеющими непосредственное отношение к миру бизнеса: Кэмерон Хоули (1905-1969) был исполнительным директором в Armstrong Cork Company, и он, несомненно, знал, о чем пишет. Условно его произведения можно отнести к жанру «производственного романа»: он исследует психологические тонкости бизнеса как отдельной сферы деятельности человека. Его основные романы, большинство из которых не переведено на русский язык, отражают глубокое понимание бизнесмена как личности и, в то же время, являются увлекательным чтением. Айн Рэнд (она же - Алиса Розенбаум) - русская эмигрантка, буквально «взорвавшая» мир американского бизнеса своими философскими идеями и романами, снимавшими вину с предпринимателей и делавшими их «атлантами», на плечах которых держится вся продуктивная американская жизнь ${ }^{1}$.

Айн Рэнд, как следует из замечаний ряда американских исследователей [8-10], могла читать романы Хоули (или он ее - единства во мнениях тут нет), часть из которых написана почти одновременно с ее собственными. Однако задача нашего исследования - не показать, кто у кого заимствует сюжетные элементы и идеи (которые порой имеют параллели), но продемонстрировать своеобразие в изображении центрального персонажа романов обоих писателей - бизнесмена. Для этого прежде всего следует выявить истоки формирования такого персонажа у двух авторов.

Говоря о ранних героях Айн Рэнд, следует вспомнить, что ее первый роман «Мы живые» (We The Living, 1936) был создан под влиянием травмы Октябрьской революции, поэтому его главный герой -

${ }^{1}$ Из писем Айн Рэнд [7] видно, что она поддерживала общение со многими американскими бизнесменами и оказывала на них влияние. Среди них - Де Витт Эмери (глава National Small Business Men's Association), Том Гирдлер (основатель и председатель Republic Steel и Vultee Aircraft), Джеральд Лоэб (вицепрезидент E.F.Hutton and Co) и др. 
это герой a la Александр Керенский. Это типаж революционера, Героя в высшем смысле этого слова, о котором писательница говорила: «В романтическом искусстве герой - не среднестатистическая единица, а абстракция лучшего и высшего, что есть в человеке» [11. С. 126]. Он характерен для русской литературы и фигурирует в романах Н.Г. Чернышевского, И.С. Тургенева, Ф.М. Достоевского, а также в более поздних беллетристических романах В. Ропшина, М. Арцыбашева, 3. Гиппиус и др. Речь идет о так называемом подпольном человеке, своеобразном мученике революции [12], немалую роль в создании которого сыграл «сверхчеловек» Ф. Ницше в интерпретации В. Соловьева. О том, что прототипом Лео Коваленского был именно Керенский, сообщает следующий факт: он был кумиром детства А. Розенбаум. Б. Бранден упоминает в своей книге о писательнице, что комната Алисы Розенбаум была обклеена его фотографиями [13]. Именно Керенскому, единственному из русских, она напишет с просьбой прочитать «Мы живые» и выразить свое мнение: «Of all great Russian people in the world, your opinion is the most valuable to me...» [7. Р. 42]. Можно сказать, что Керенский - первая любовь писательницы, ее первый герой, которого она будет всю дальнейшую жизнь «рисовать» в своих романах. Черты этого героя, во многом романтического, мы обнаружим в персонажах ее более поздних романов. Лео Коваленский никогда не занимался бизнесом, но его авантюризм, «базбашенность», готовность рискнуть жизнью ради свободы - те свойства характера, которые будут доминировать в характере Говарда Рорка, Хэнка Риардена, Джона Голта, Рагнера Даннескьолда, героев ее поздних романов.

В образе Лео Коваленского проявился русский революционер индивидуалистского толка, борющийся против свершившейся Октябрьской революции: «Его рот, спокойный, жесткий, презрительный, был словно рот древнего вождя, который мог приказать людям пойти на смерть, а глаза были такими, что могли бы спокойно взирать на это» [14. С. 55]. И если Лео Коваленский не выдержал проверку трудностями, став обыкновенным прожигателем жизни, то Рагнер Даннескьолд - пират, анти-Робин Гуд из последнего романа Рэнд «Атлант расправил плечи», отбирает деньги у паразитов, сидящих на шее у предпринимателей: «А я - тот, кто грабит бедных и отдает деньги богатым, или, если быть точным, человек, который 
грабит бедных воров и возвращает деньги богатым людям, способным производить ценности» [15. С. 7]. А Говард Рорк, главный героя романа «Источник», взрывает здание, возведенное по искаженному им проекту, выражая тем самым бунт против коллективизма. Джон Голт, вершина антропологического идеала писательницы, и вовсе тайно «останавливает мотор, движущий миром».

Если герой-революционер был типичным героем русской литературы XIX-XX вв., то популярным героем массовой американской литературы XX в. становится супермен, впервые появившийся в комиксах компании DC Comics. Как отмечает У. Эко, данный тип героя был порожден неудобствами, которые ощущает человек индустриального общества, а его двойничество - типичный прием массовой литературы, позволяющий читателю отождествить себя с суперменом. Эко констатирует: «Идентифицируя себя с таким персонажем, любой бухгалтер в любом американском городке может тайно питать надежду, что в один прекрасный день из кокона его обыденной личности может вылупиться сверхчеловек, способный искупить годы прозябания и посредственности» [16. С. 231]. Эко также отмечает крайнюю ограниченность супермена в амбициях и устремлениях: он «легко совершает путешествия в другие галактики, а остальной земной мир и даже остальную Америку практически игнорирует» [16. C. 262]. Резюмируя, исследователь сообщает о том, что американский супермен - «это совершенный образец гражданского сознания, полностью отделенного от сознания политического» [16. С. 263].

Таким образом, «сверхчеловек» американской литературы коренным образом отличается от такового в русской: у него нет задачи совершить глобальную «перестройку», он ориентирован на решение более обыденных проблем. Так, герой романов одного из самых популярных в США мастеров детектива ХХ в. Мики Спиллайна (который, кстати, был близким другом Айн Рэнд) Майкл Хаммер - одна из самых известных «инкарнаций» образа супермена в американской массовой литературе.

Для начала следует отметить, что типаж предпринимателя у обоих писателей не является однородным: можно выделить как минимум три подтипа. Первый - это удачливый делец, за кулисами руководящий процессами большого бизнеса. Второй - это так называемый отец корпорации, сильный и авторитарный управленец. Третий 
- это практичный финансист, главной целью которого является чистая прибыль. Четвертый - это симбиоз талантливого ученого и предпринимателя. Каждый из подтипов очевидно отличается от других отношением к предпринимательству: для первого бизнес - это «чистое искусство», для второго - родное детище, для третьего - источник прибыли, для четвертого - способ самореализации.

Удачливый делец, стоящий «за спиной» большого бизнеса у Хоули - это, конечно, главный герой его одноименного романа, Кэш МакКолл (Cash McCall, 1955). Очевидной параллелью, которую подметили критики, оказывается сходство этого героя с фигурой Джона Голта («Атлант расправил плечи»). Сходство обнаруживается уже в говорящих фамилиях персонажей (gold с англ. - золото, cash наличные деньги), однако на этом не заканчивается. «Таинственная фигура, которая бродит по земле» (M. Enright [8]) - это описание одинаково применимо к обоим персонажам. Первый руководит нитями этого мира тайно, «выдергивая» из общества нужных ему людей и создавая собственное сообщество в долине Джона Голта, второй же скупает обанкротившиеся предприятия, перепродавая их и делая прибыльными. Оба героя на протяжении большей части повествования остаются «за кадром», «в полный рост» появляясь ближе к концу и в обоих случаях - в эпизоде, связанном с изображением утопической страны. Портретная характеристика Джона Голта и Кэш МакКолла также схожа. В последней главе романа Айн Рэнд («Атлантида») в портретном описании героя есть мотив металла («hе looked as he were poured out of metal... soft-lustered metal, like an aluminum-copper alloy...» [17. Р. 574]. Кэш МакКолл описан похоже («every line were about to be etched into a copper» [18. Р. 269]). Кроме того, в описании внешности обоих героев содержится указание на их необыкновенную целостность, отсутствие ощущения «маски» при смене эмоций. Джон Голт: «It seemed to her for a moment that she was in the presence of a being who was pure consciousness...» [17. P. 643]. Лицо Кэша описано подобным образом: «His was a living face, the mirror of a mind unshackled by convention, soaring its own free course without of apology for freedom, regarding pleasure not as a frivolity to be grudgingly tolerated but as something organically linked to life itself...» [18. P. 275-276]. 
Помимо чисто внешних сходств, существует близость заявленных позиций обоих героев. Оба - сильные личности, умеющие добиваться поставленных целей и руководящие миром с его «изнанки». Однако какова природа the romance of business в обоих текстах и столь ли она одинакова, как кажется на первый, весьма поверхностный, взгляд? В дискуссии Гила Кларка и Уинстона Конвея относительно того, кто таков на самом деле Кэш МакКолл - ловкий делец без совести или личность, творящая добро - звучит крайне важная для Айн Рэнд мысль о моральности самой идеи бизнеса: «They're becoming rare, you know, men who recognize the difference between a thing being morally right and legally right» [18. Р. 252]. В своей статье «Что такое капитализм?» (What Is Capitalism?, 1965) Рэнд пишет: «Нравственное оправдание капитализма (the moral justification of capitalism) в том, что это единственный уклад, созвучный природной разумности человека, гарантирующий человеку человеческое существование и руководимый принципом справедливости» [19. С. 22]. Как философ Рэнд была против исключения моральности из критериев оценивания того или иного явления (в этом заключался и ее спор с Ф. Ницше) $)^{2}$, поэтому здесь ее взгляды будто бы совпадают со взглядами Хоули. Однако прочитаем дальше.

В своем споре о личности МакКолла Кларк и Конвей касаются нравственного оправдания того, чем он занимается, а именно скупки и перепродажи обанкротившихся предприятий. Кларк, преуспевающий строитель, заявляет: «I just don't see what he can accomplish with the kind of life he leads» [18. Р. 253]. По его мнению, его жизнь совершенно бессмысленна, ведь он просто делает деньги, но не создает с нуля ту компанию, которую покупает, лишая себя, так образом, чувства удовлетворения. Конвей возражает ему, подчеркивая, что он строитель ( a builder), а МакКолл - торговец (a trader). Здесь и начинается принципиальное расхождение между Хоули и Рэнд.

Айн Рэнд избегала разделять бизнесмена (того, кто делает деньги) и интеллектуала (того, кто создает новое). В своем программном эссе For The New Intellectual (1961) философ формулирует черты идеального «нового интеллектуала»: это тот, кто будет объединять в

${ }^{2}$ См., например, ее статью «Культ нравственной серости» (The Cult of Moral Grayness, 1964). 
себе черты the practical thinker и the philosophical businessman [20]. Действительно, ее герои - вовсе не обычные бизнесмены, которые просто покупают и продают предприятия, как Кэш МакКолл. Важной и отличительной чертой романов Айн Рэнд является изображение в них героя в процессе становления, исканий, эволюции. Как верно отмечает C.M. Sciabarra, это - черта русского романа: в каноническом отношении романы Айн Рэнд фактически повторяют жанровую форму русского романа, в котором герой является воплощением абстрактного принципа, а значит единственной формой психологического роста в нем будет преодоление психологического дуализма $[21]^{3}$. Ключевым вопросом русского классического романа всегда был поиск героя, который олицетворял бы «движение времени», поиск ответов на «вечные» вопросы: «Герои русской литературы - это образы не реальных людей и отношений, а отражение проблем, которые мучили образованное общество. Это литература не натуралистическая и не реалистическая, а экзистенциальная» [23].

Так, Джон Голт - это герой, имеющий отчетливо сформулированную цель и неуклонно идущий к ней, причем эта цель сформулирована на редкость амбициозно и глобально: «Я остановлю мотор, движущий мир» [15. С. 10]. Как выражение абстрактного принципа герой Рэнд - полная противоположность герою Хоули, преследующему очень реальные и земные цели. Это особенно заметно в утопическом эпизоде об Атлантиде, который присутствует в обоих романах и вносит решающий вклад в формирование суждения о нацио-

3 Эту «схему» психологического роста героя в произведениях Айн Рэнд анализирует C.M. Sciabarra. По его мнению, герой Рэнд подавляет эмоции (исходящие от его разума) из-за социального давления, однако затем разум берет вверх и он начинает обретать целостность эмоций и мыслей. В качестве наиболее яркого примера он приводит эволюцию Хэнка Риардена в романе «Атлант расправил плечи», который, влюбляясь в Дагни Таггарт, подавляет в себе эти эмоции, потому что считает их (из-за стереотипов общества) греховными, однако осознав причину своих противоречивых эмоций, перестает испытывать ощущение «расколотого» сознания [21. С. 173]. Известна цитата из этого же романа: «Дам тебе намек. Противоречий не существует. Если ты усматриваешь где-то протворечие, проверь исходные данные. И найдешь ошибку в одном из них» [22. С. 253]. Данная схема является универсальной для всех художественных произведений писательницы. 
нальной специфике героя-предпринимателя в обоих текстах: утопия Хоули принципиально гедонистична и служит лишь «декорацией» в романтической линии отношений Кэша и Лори. Рэнд же конструирует мессианский тип Атлантиды, где утопия является самоцелью и формирует проекции представлений об идеальном обществе абстрактного принципа, выраженного в лице Джона Голта.

Джон Голт - это «человек-обманка»: «в миру» он обычный путевой смотритель, в Атлантиде же - гениальный изобретатель: «Ты был путевым обходчиком здесь - здесь! - двенадцать лет...» [24. C. 297], - скажет Дагни, встретив его на пассажирской платформе. Джон Голт стремится превратить утопию в реальность, причем, со свойственной русской утопии претензией на глобальность (это качество, по мнению В. Мильдона, является ведущим именно в русской утопии, приводя в пример «Что делать?» Чернышевского, «Красную звезду» Богданова и другие тексты [25]): вернуться в Америку из Атлантиды, чтобы воплотить свой проект в жизнь. Франсиско д’Анкония заявляет, что «возрождение “Д'Акония Коппер” и всего мира должно начаться отсюда, из Соединенных Штатов» [24. С. 88]. Ничего подобного мы, разумеется, не найдем у Хоули: его утопия строго «для личного пользования». К. Чистов отмечает, что сюжет о «царе-избавителе» был свойствен всем культурам, однако только в русской он имеет мотивы воцарения ради освобождения народа [26. C. 248]. Также он отмечает, что «изображение изгнания, странствий или заточения не в неопределенном (как в сказке) и не в историческом прошлом (как в эпосе или исторических преданиях), а в настоящем и мотив победы героя в будущем и составляют основное отличие сюжета наших легенд от близких сюжетов и в других жанрах» [26. C. 248].

Особо стоит отметить мотив «тайного хождения» царяизбавителя «с целью разглядеть и запомнить все народные обиды, чтобы потом отомстить обидчикам» [26. С. 251]. Казалось бы, этот мотив есть как у Хоули, так и у Рэнд: у первого Кэш МакКолл тайно скупает и перепродает обанкротившиеся предприятия, у второй - вообще организована целая «сеть» тайных шпионов-атлантов по всей стране, которые устраивают различные диверсии, чтобы помешать врагам. Однако только у Рэнд утопический проект приобретает характер реализации задуманного: в финале романа атланты приходят в 
мир, погруженный в хаос: «-Путь расчищен, - сказал Голт. - Мы возвращаемся в мир» [24. С. 534].

Рэнд, таким образом, создает героя-«сверхчеловека» в том смысле, какой в нее вкладывала русская литература: он есть носитель «идеи», с помощью которой будет меняться мир вокруг него. Кэш МакКолл же оказывается ближе к типажу американского супермена: его не волнуют «дальние рубежи», вся его деятельность ограничивается удовольствием покупать и продавать компании, он торговец в американском, строго прагматическом смысле этого слова, у него отсутствует та составляющая, которая есть у Джона Голта: он не мессия, несмотря на свои выдающиеся качества дельца.

Другой тип героя, который присутствует как у Хоули, так и у Рэнд, - это «отец корпорации». Свойственный в большей степени роману Хоули, у него он предстает в образе Эвери Булларда (Executive Suit, 1952). Буллард - талантливый управленец, лидер компании Tredway Corporation, занимающейся производством мебели. Смерть лидера компании нарушает привычный ритм ее работы, внося хаос в совет директоров, внутри которого разворачивается серия интриг вокруг директорского кресла. Во втором романе Хоули еще острее возникает тема несправедливого отношения к крупным бизнесменам, о которой Рэнд писала в своей статье «Большой бизнес - преследуемое меньшинство американского общества» (America's Persecuted Minority: Big Business, 1963). Две позиции относительно этого вопроса сталкиваются в романе в диалоге Джулии Трэдуэй Принс и Дона Уоллинга: первая представляет точку зрения на бизнесмена как диктатора, второй - как на того, на ком держится все дело компании. Принс при этом демонстрирует иррациональный взгляд на фигуру Булларда, отмечая, что его невозможно понять и сравнивая с магом, который совершает немыслимые трюки [27. С. 271]. Называя его стиль управления компанией «диктаторским», Джулия обвиняет Булларда в том, что он принимал все решения относительно компании единолично. В конечном счете весь спор Джулии и Дона сводится к спору о роли личности в истории: была бы, например, Америка такой, какая она есть без Рузвельта? А без Вашингтона? А без Линькольна? А без Джефферсона? [27. С. 273]. Где границы влияния одного человека на историю компании (государства)? 
Хэнк Риарден, «отец корпорации» Риарден Стил отвечает на этот вопрос однозначно: «Вы оскорбляете меня не за мои грехи, а за мои добродетели. Вы сами называете их добродетелями, поскольку ваша жизнь зависит от них; они нужны вам, и вы не в состоянии разрушить мои достижения, вы можете завладеть ими только силой» [15. C. 268]. Индивидуализм Риардена не позволяет ему уступить «Чудесный металл» (имя которому присвоили «паразиты», не понимая роли разума в его создании), открытие которого принадлежит ему (несмотря на то, что в его воплощении и распространении участвовали десятки и сотни людей). Хоули и Рэнд, таким образом, одинаково понимают проблему кризиса свободного предпринимательства в США. Айн Рэнд, которая опасалась национализации частной собственности в Америке, с тревогой наблюдая за «призраком социализма» над ней, могла бы подписаться под пассажами из романа Хоули Cash MacCall, в которых он говорит о непомерных налогах и чрезмерном государственном контроле как о причинах банкротства крупных американских корпораций. И спасением от этого может стать сильный управленец, человек, который возьмет на себя всю ответственность за корпорацию.

Но романах обоих авторов представлен и противоположный тип дельца - прагматичный финансист, считающий прибыль компании первостепенной для ее развития, а ее акционеров - ее полноправными владельцами наряду с лидером компании. Такой тип предпринимателя является, безусловно, негативным типажом в романах Рэнд и Хоули. В романе Executive Suit Лорен Шоу, один из вицепрезидентов компании Tredway Corporation, называет Эвери Булларда «устаревшим» типом управленца, провозглашая высшим благом компании количество проданной мебели (без учета ее качества), а также критикуя индивидуалистский стиль управления компанией. Похожим образом ведет в себя в последнем романе Рэнд Джим Таггерт, президент Таггерт Трансконтинентал, который отдает Мексике поезда компании, несмотря на явные проблемы, возникающие от этого у самой компании. Акт альтруизма дорого обходится корпорации: поезда начинают сходить с рельсов, чего прежде никогда не бывало. Если Хоули лишь намекает на возможные экономические проблемы, которые могут возникнуть в Америке, если к власти придет такой тип управленца, как Лорен Шоу, то Рэнд описывает уже 
сам процесс разрушения крупного бизнеса в США и его последствия для глобальной экономики (глобальность - черта именно русского (анти)утопического текста).

Вместе с тем ни Хоули, ни Рэнд не отдают пальму первенства «патерналистскому» стилю управления бизнесом. У Хоули в его втором романе директорское кресло займет Макдональд Уоллинг, который изначально предстает перед читателем в роли талантливого ученого, работающего в корпорации над разработкой новых материалов для мебели. Однако уже в финале романа он читает пламенную речь перед советом директоров о новом типе управленца, в котором остро нуждается компания (подобно тому, как Джон Голт из романа Айн Рэнд читает речь перед публикой о роли индивидуализма в социально-экономической жизни США). Уоллинг задает Шоу вопрос: «Do you really think a man of that caliber would be willing to sell his life for money - for what would be left out of sixty thousand a year after taxes?» [27. C. 303]. Сравнивая корпорацию с живым человеком, он заявляет: «No man can work for money alone. It`s enough» [27. C. 304]. А работать такой человек, по мнению Уоллинга, может только ради того, чтобы «быть на вершине башни» («at the top of the tower»). Подчеркивая, что Буллард упускал из виду, что компания - это все же не один человек, это «армия», Уоллинг сообщает, что качество продукции компании всегда важнее количества, которое ею продано: это повышает самооценку работников, позволяя им гордиться производимой ими продукцией (в фильме 1954 г. по мотивам романа этот момент показан еще более ярко: Уоллинг разбивает дешевый стол, который производит компания, отрывая ему ножки). Резюмируя свою речь, Дон призывает компанию развиваться и меняться, выпуская продукцию высокого качества, после чего под аккомпанемент аплодисментов избирается директором Tredway Corporation.

Айн Рэнд показывает новый тип управленца более «выпукло», вкладывая в его создание определенную философию. Основная работа, в которой описан ее идеал, - For The New Intellectual (1961). В этом трактате она обеспокоена «интеллектуальным банкротством» Америки и обвиняет в этом философию иррационализма, захлестнувшую мир. Выход она видит в рождении нового типа человека, «нового интеллектуала», созданного по образцу идеализированных ею «отцов-основателей» США. Это человек мысли и действия одно- 
временно, он преодолел дихотомию «разум-душа» ('soul-body dichotomy'), он сочетает в себе свойства философа и предпринимателя: «The New Intellectual will be a reunion of the twins who should never have been separated: the intellectual and the businessman» [20. P. 43]. В своей лекции, прочитанной в отеле Астор в Нью-Йорке 21 декабря 1961 г., Рэнд призывает американских предпринимателей тщательнее выбирать систему ценностей, которой они следуют, не принимать на веру философские идеи, которые могут оказаться губительными для них [28]. Такая озабоченность философским образованием бизнесмена обусловлена как раз русским происхождением писательницы: ее детство было отмечено одним из самых переломных событий в истории России, да и всего мира - Октябрьской революцией. Как известно, она была «сделана» именно на деньги предпринимателей (об этом в художественной форме рассказывает в своем романе «Самоубийство» Марк Алданов). Именно поэтому она создает философию, в которой развитию интеллекта предпринимателя уделяется важное место. В свою очередь, данная философия находит свое отражение в ее романах.

Так, Гейл Винанд, газетный магнат из романа «Источник», не выбирающий средств на пути зарабатывания денег и интересующийся только властью, терпит крах, поскольку привык слушать мнение толпы. Так как Рэнд изображала даже не реальных людей, а принципы, стоящие за ними, она описывала каждый характер и те философские идеи, которые он должен иллюстрировать, в своем дневнике. О Гейле Винанде она напишет: «A man who rules the mob only as long as he says what the mob wants him to say» [29. P. 102]. Напротив, Джон Голт, как квинтэссенция integrated man в ее текстах, предстает как человек, главное качество которого - равновесие: «No change in him, because he has no intellectual contradiction and, therefore, no inner conflict» [29. Р. 481]. Это воплощенный идеал, однако заметим, что именно Джон Голт не является предпринимателем в том смысле, в котором он фигурирует в романах Хоули. Это не просто владелец некоей корпорации (или даже его скупщик, как Кэш МакКолл), но человек, который пытается изменить принципь устройства мира. Если предыдущие герои-предприниматели в романах Рэнд лишь приближались к этому идеалу (их интересовала лишь 
судьба их собственной компании), то Джон Голт озабочен судьбой буквально всей страны, и даже шире - мира.

Сравнивая романы двух писателей в аспекте их национальной специфики, можно заключить, что Кэмерон Хоули и Айн Рэнд равно обеспокоены положением предпринимателя в Соединенных Штатах Америки. Оба так или иначе отмечают кризис «американской мечты», который заключался в стремлении к голой наживе без высокой цели самореализации предпринимателя. Такие типажи бизнесменов, бессмысленно зарабатывающих деньги и тратящих их, воплощены в романах С. Льюиса «Бэббит», Т. Драйзера «Финансист» и др. Америка теряет ценности «отцов-основателей», на которых зиждется американская ментальность - свободолюбие, стремление к счастью и личному успеху. Как Хоули, так и Рэнд главную причину этого видят в государственном контроле над экономикой и ущемлении прав бизнесменов.

Однако существует большая разница между тем, как изображены и что символизируют собой герои-предприниматели в романах двух писателей. Если героев романов Хоули интересуют личный успех, счастье и социальный статус (темы американской литературы), то герои Рэнд, несмотря на кажущийся радикальный индивидуализм, в конечном счете стремятся к тому, как переустроить мир, спасти человечество (темы русской литературы). Оба автора пишут о неудовлетворенности предпринимательства сложившейся в стране ситуацией и стремятся найти пути возрождения «американской мечты». В качестве средства предлагается «новая религия» (т.е. стремление к чему-то большему, чем просто деньги): у Хоули это - дело спасения компании, у Рэнд - дело спасения нации. Пафос текстов Хоули стремление к личному успеху, процветанию компании и его членов или даже только отдельного человека (так, Кэш МакКолл с чистой совестью использует бедственное положение разорившихся бизнесменов), пафос текстов Рэнд - спасение Америки (именно ради этого создается Атлантида). Как следствие, для воплощения данной задачи необходимы разные типы героев: у Хоули это - предприимчивый герой, умеющий либо делать деньги, либо развивать компанию (и то, и другое одновременно делать ни Кэш МакКолл, ни Дон Уиллинг всетаки не в состоянии), у Рэнд - «сверхчеловек», объединяющий качества интеллектуала и предпринимателя. 
В конечном счете благо компании в романах Хоули всегда становится на первое место, а Макдональд Уоллинг - лишь слабая «тень» лучших героев Рэнд, попытка (и довольно неудачная) воплотить в нем качества героя целостного - типаж ученого-предпринимателя (а может, такая задача и вовсе не ставилась автором). У Рэнд благо Америки и ее переустройство становятся важнее блага отдельной корпорации, как бы ни пыталась писательница замаскировать эту интенцию под индивидуалистическими заявлениями: именно для этого «атланты» и разрушают мир до основания, чтобы вернуться в него уже с собственными ценностями.

Возвращаясь к разговору о специфике развития образа предпринимателя в американской и русской культурах, вспомним, что именно для русской культуры был свойствен разрыв между дворянством и предпринимателями, а также ними и народом. По сути, дворяне были образованы, но не имели практической жилки, а купцы умели применять знания на практике, но не имели фундаментального образования ${ }^{4}$. В Америке, напомним, было противопоставление предпринимательства и народа, но страна не знала этого глубинного разрыва между интеллигенцией и классом предпринимателей. Именно в этом, на наш взгляд, и заключается причина возникновения антропологического идеала, который конструирует Айн Рэнд в своих философских романах: стремясь к преодолению этого разрыва, она создает образ integrated man, объединяя в нем качества интеллектуала и бизнесмена, интуитивно еще раз проживая травму Октябрьской революции, которая была с нею всю ее жизнь. Кэмерон Хоули такого опыта, конечно, не имел - именно в этом и кроется глубокая разница между изображением предпринимателя в его романах и романах Рэнд, которые внешне кажутся похожими.

\footnotetext{
${ }^{4}$ Глубинный же конфликт между интеллигенцией и народом (и между предпринимателями и народом), по мнению Г. Белой, и породил феномен Октябрьской революции: «Русская культура со временем петровских реформ стала развиваться несинхронно: рядом с дворянской субкультурой (субкультурой образованного класса) существовала крестьянская субкультура. Конечно, сосуществование субкультур - “низовой” и “высокой” - является константной величиной в любом обществе. Нигде, однако, их сосуществование не доходило до конфликта, до противостояния, до такого разрыва, какой оно имело место в России» [30. С. 37].
} 


\section{Литература}

1. Бодрийяр Ж. Америка. М.: Владимир Даль, 2000. 208 с.

2. Голенопольский T. Народ, да! Из американского фольклора. М.: Правда, 1983. 480 c. URL: http://skazka.mifolog.ru/books/item/f00/s00/z0000035/st047.shtml

3. Баталов Э.Я. Русская идея и американская мечта. М.: Прогресс-Традиция, 2009. $384 \mathrm{c}$.

4. Варламова E.В. Образ Америки в литературе США первой половины XX века (Ш. Андерсон, Д. Дос Пассос, Т. Уайлдер): автореф. дис. ... канд. филол. наук. Казань, 2010. 24 с.

5. Зарубина Н.Н. Российский предприниматель в художественной литературе XIX - начала XX века // Общественные науки и современность. 2003. № 1. С. 101-115.

6. Недзвецкий B.A. История русского романа XIX века: неклассические формы: Курс лекций. М.: Изд-во Моск. ун-та, 2011. 152 с.

7. Letters of Ayn Rand / ed. by M.S. Berliner. N.Y.: A Plume Book, 1997. 682 p.

8. Enright M. Hawley's Heroes and the Romance of Business // The Atlas Society. URL: https://atlassociety.org/commentary/commentary-blog/4581-hawleys-heroesand-the-romance-of-business

9. Merrill R.E. The Ideas of Ayn Rand. Chicago: Carus Publishing Company, 1991. $212 \mathrm{p}$.

10. Powell R. Taking Pieces of Rand with Them: Ayn Rand's Literary Influence // The Journal of Ayn Rand Studies. 2012. Vol. 12, № 2. P. 207-235.

11. Рэнд A. Эстетический вакуум нашего времени // Рэнд А. Романтический манифест: Философия литературы. М.: Альпина Паблишер, 2011. С. 123-128.

12. Могильнер М. Мифология «подпольного человека»: радикальный микрокосм в России начала XX века как предмет семиотического анализа. М.: Новое литературное обозрение, 1999. 208 c.

13. Branden B. The Passion of Ayn Rand. N.Y.: Doubleday, Garden City, 1986. $442 \mathrm{p}$.

14. Рэнд А. Мы живые. М.: Альпина Паблишерз, 2011. 473 с.

15. Рэнд А. Атлант расправил плечи: в 3 ч. М.: Альпина Бизнес Букс, 2009. Ч. $2.424 \mathrm{c}$.

16. Эко У. Роль читателя. Исследования по семиотике текста. М.: Изд-во ACT: CORPUS, $2016.640 \mathrm{c}$.

17. Rand A. Atlas Shrugged. N.Y.: A Signet Book, 1996. 1080 p.

18. Hawley C. Cash McCall. N.Y.: Open Road Integrated Media, 2015. 499 p.

19. Рэнд A. Что такое капитализм? // Рэнд А. Капитализм: Незнакомый идеал. М.: Альпина Паблишер, 2016. С. 11-40.

20. Rand A. For the New Intellectual. N.Y.: Random House Inc., 1961. 159 p.

21. Sciabarra C.M. Ayn Rand. The Russian Radical. Pennsylvania: Pennsylvania State University Press, 2013. 526 p.

22. Рэнд А. Атлант расправил плечи: в 3 ч. М.: Альпина Бизнес Букс, 2009. Ч. $1.436 \mathrm{c}$. 
23. Аксючии В. Русский характер. Статья 3: Экзистенциальная боль русской литературы. URL: http://www.pravoslavie.ru/jurnal/071112103826.htm

24. Рэнд А. Атлант расправил плечи: в 3 ч. М.: Альпина Бизнес Букс, 2009. Ч. $3.538 \mathrm{c}$.

25. Мильдон В. Санскрит во льдах, или Возвращение из Офира: Очерк русской литературной утопии и утопического сознания. М.: Российская политическая энциклопедия, 2006. $288 \mathrm{c}$.

26. Чистов K.B. Русская народная утопия (генезис и функции социальноутопических легенд). СПб.: ДМИТРИЙ БУЛАНИН, 2011. 528 с.

27. Hawley C. Executive Suit. N.Y.: Open Road Integrated Media, 2015. 321 p.

28. Rand A. Capitalism vs Communism: видеозапись лекции Айн Рэнд. URL: https://www.youtube.com/watch?v=n8XuKqQppWU

29. Journals of Ayn Rand / ed. by D. Harriman. N.Y.: A Plume Book, 1999. 659 p.

30. Белая Г.А. Дон Кихоты революции - опыт побед и поражений. М.: РГГУ, 2004. $623 \mathrm{c}$.

\section{Specificity of the National Character in the Description of Entrepreneurs in Cameron Hawley's and Ayn Rand's Novels}

Imagologiya i komparativistika - Imagology and Comparative Studies, 2020, 14, pp. 122-142. DOI: 10.17223/24099554/14/6

Anastasiya V. Grigorovskaya, Tyumen State University (Tyumen, Russian Federation). E-mail: a.v.grigorovskaya@utmn.ru

Keywords: image of entrepreneur in literature, national character, Russian literature, American literature, Ayn Rand, Cameron Hawley.

The novels of the American writer Cameron Hawley (Cash McCall, Executive Suit) and the American writer and philosopher from Russia Ayn Rand (Fountainhead, Atlas Shrugged) are analyzed in the article. The entrepreneur image that has a brightly expressed national specificity is the key image for the comparison. In the first part of the research, a review of the genealogy of the national image of the entrepreneur as a character is done, and the evolution of this image in Russian and American cultures is traced. The conclusion here is that the image of a businessman in American literature was positive until the middle of the 20th century, the time of the crisis of the American dream, while the image of an entrepreneur in Russian literature was always primarily negative because of the gap between two types of rationality - practical and axiological (N. Zarubina). In the second part of the research, the roots of entrepreneur images of both authors are identified. The conclusion here is that, the basis of Rand's latest characters is the image of a Russian revolutionist à la Kerensky (Leo Kovalensky in her first novel We The Living), which is expressed in their adventurism, irreconcilable individualism, and love of freedom. The genetic basis of Hawley's characters is the image of the American superman limited in his ambitions (U. Eco), which is different from the Russian hero who always focuses on global achievements. In the third part of the research, the author distinguishes four types of entrepreneurs as characters in the both authors' novels: a lucky businessman who runs a business behind 
the scenes, an authoritarian leader, a pragmatic fantasist, a symbiosis of a talented scholar and an entrepreneur. Despite the external resemblance of the two writers' characters, the research shows that Rand's character does not have the dichotomy of that of Hawley: Rand formulates the ideal of a "new intellectual" (For The New Intellectual) aiming to overcome Russian culture's being torn between the two rationality types. Rand's character, unlike Hawley's, is an ideologist, and he has messianic features. Hawley's attempt to combine the thinker and the businessman in the image of MacDonald Walling was unconvincing: Walling thinks only about his personal success and the company's interests (the topics of American literature) while John Galts's efforts focus on the improvement of the life of the country and humankind as a whole (the topics of Russian literature). In the conclusion, the author states that, despite the external similarity of the writers' entrepreneur characters, Ayn Rand endows the entrepreneur image with features inherent in Russian literature, and Cameron Hawley depicts characters typical for American literature.

\section{References}

1. Baudrillard, J. (2000) Amerika [America]. Translated from French by D. Kalugin. Moscow: Vladimir Dal'.

2. Golenopol'skiy, T. (1983) Narod, da! Iz amerikanskogo fol'klora [Folk, yes! From American folklore]. Moscow: Pravda. [Online] Available from: http://skazka.mifolog.ru/books/item/f00/s00/z0000035/st047.shtml.

3. Batalov, E.Ya. (2009) Russkaya ideya i amerikanskaya mechta [The Russian Idea and the American Dream]. Moscow: Progress-Traditsiya.

4. Varlamova, E.V. (2010) Obraz Ameriki v literature SShA pervoy poloviny XX veka (Sh. Anderson, D. Dos Passos, T. Uaylder) [The Image of America in the Literature of the United States of the First Half of the 20th Century (S. Anderson, J. Dos Passos, T. Wilder)]. Abstract of Philology Cand. Diss. Kazan.

5. Zarubina, N.N. (2003) Rossiyskiy predprinimatel' v khudozhestvennoy literature XIX - nachala XX veka [Russian entrepreneur in the fiction of the 19th - early 20th centuries]. Obshchestvennye nauki i sovremennost' - Social Sciences and Contemporary World. 1. pp. 101-115.

6. Nedzvetskiy, V.A. (2011) Istoriya russkogo romana XIX veka: neklassicheskie formy: Kurs lektsiy [History of the 19th-century Russian novel: Non-Classical Forms: Lectures]. Moscow: Moscow State University.

7. Berliner, M.S. (ed.) (1997) Letters of Ayn Rand. N.Y.: A Plume Book.

8. Enright, M. (2020) Hawley's Heroes and the Romance of Business. [Online] Available from: https:/atlassociety.org/commentary/commentary-blog/4581-hawleysheroes-and-the-romance-of-business.

9. Merrill, R.E. (1991) The Ideas of Ayn Rand. Chicago: Carus Publishing Company.

10. Powell, R. (2012) Taking Pieces of Rand with Them: Ayn Rand's Literary Influence. The Journal of Ayn Rand Studies. 12 (2). pp. 207-235. 
11. Rand, A. (2011) Romanticheskiy manifest: Filosofiya literatury [The Romantic Manifesto: A Philosophy of Literature]. Translated from English by M. Sukhanova, Ya. Tokareva. Moscow: Al'pina Pablisher. pp. 123-128.

12. Mogil'ner, M. (1999) Mifologiya "podpol'nogo cheloveka": radikal'nyy mikrokosm v Rossii nachala XX veka kak predmet semioticheskogo analiza [Mythology of the "Underground Man": A Radical Microcosm in Russia at the Beginning of the 20th Century as an Object of Semiotic Analysis]. Moscow: Novoe literaturnoe obozrenie.

13. Branden, B. (1986) The Passion of Ayn Rand. N. Y.: Doubleday, Garden City.

14. Rand, A. (2011) My zhivye [We the Living]. Translated from English. Moscow: Al'pina Pablisherz.

15. Rand, A. (2009a) Atlant raspravil plechi: V 3 ch. [Atlas Shrugged: In 3 Parts]. Translated from English. Pt. 2. Moscow: Al'pina Biznes Buks.

16. Eco, U. (2016) Rol' chitatelya. Issledovaniya po semiotike teksta [The Role of the Reader: Explorations in the Semiotics of Texts]. Translated from English and Italian by S. Serebryanyy. Moscow: Izd-vo AST: CORPUS.

17. Rand, A. (1996) Atlas Shrugged. N.Y.: A Signet Book.

18. Hawley, C. (2015) Cash McCall. N.Y.: Open Road Integrated Media.

19. Rand, A. (2016) Kapitalizm: Neznakomyy ideal [Capitalism: The Unknown Ideal]. Translated from English. Moscow: Al'pina Pablisher. pp. 11-40.

20. Rand, A. (1961) For the New Intellectual. N. Y.: Random House Inc.

21. Sciabarra, C.M. (2013) Ayn Rand. The Russian Radical. Pennsylvania: Pennsylvania State University Press.

22. Rand, A. (2009b) Atlant raspravil plechi: $V 3$ ch. [Atlas Shrugged: In 3 Parts]. Translated from English. Pt. 1. Moscow: Al'pina Biznes Buks.

23. Aksyuchits, V. (2007) Russkiy kharakter. Stat'ya 3: Ekzistentsial'naya bol' russkoy literatury [Russian Character. Article 3: The Existential Pain of Russian Literature]. [Online] Available from: http://www.pravoslavie.ru/jurnal/ $071112103826 . \mathrm{htm}$

24. Rand, A. (2009c) Atlant raspravil plechi: V 3 ch. [Atlas Shrugged: In 3 Parts]. Translated from English. Pt. 3. Moscow: Al'pina Biznes Buks.

25. Mil'don, V. (2006) Sanskrit vo l'dakh, ili Vozvrashchenie iz Ofira: Ocherk russkoy literaturnoy utopii i utopicheskogo soznaniya [Sanskrit in Ice, or Return from Ophir: An Essay on Russian Literary Utopia and Utopian Consciousness]. Moscow: Rossiyskaya politicheskaya entsiklopediya.

26. Chistov, K.V. (2011) Russkaya narodnaya utopiya (genezis i funktsii sotsial'no-utopicheskikh legend) [Russian Folk Utopia (Genesis and Functions of Social Utopian Legends)]. St. Petersburg: Dmitriy Bulanin.

27. Hawley, C. (2015) Executive Suit. N.Y.: Open Road Integrated Media.

28. Rand, A. (1961) Capitalism vs Communism. [Video]. [Online] Available from: https://www.youtube.com/watch?v=n8XuKqQppWU.

29. Harriman, D. (ed.) (1999) Journals of Ayn Rand. N. Y.: A Plume Book.

30. Belaya, G.A. (2004) Don Kikhoty revolyutsii - opyt pobed i porazheniy [Don Quixotes of the Revolution: The Experience of Victories and Defeats]. Moscow: RSUH. 